10 - ORIGINAL ARTICLE

CLINICAL INVESTIGATION

\title{
Oxidative stress in carotid arteries of patients submitted to carotid endarterectomy. The role of aging process ${ }^{1}$
}

\author{
Márcio Luís Lucas ${ }^{\mathrm{I}}$, Cristina Campos Carraro ${ }^{\mathrm{II}}$,Adriane Belló-Klein ${ }^{\mathrm{III}}$, Antônio Nocchi Kalil ${ }^{\mathrm{IV}}$, Newton Aerts ${ }^{\mathrm{V}}$
}

DOI: http://dx.doi.org/10.1590/S0102-865020160080000010

${ }^{I}$ Master in Medicine, Vascular Surgeon, Universidade Federal de Ciências da Saúde de Porto Alegre (UFCSPA), Brazil. Technical procedures, acquisition and interpretation of data, manuscript writing, critical revision.

IIPhD, Department of Cardiovascular Physiology, Universidade Federal do Rio Grande do Sul (UFRGS), Porto Alegre-RS, Brazil. Technical procedures, interpretation of data, critical revision.

IIIPhD, Associate Professor, Department of Physiology, UFRGS, Porto Alegre-RS, Brazil. Technical procedures, interpretation of data.

${ }^{\text {IV }} \mathrm{PhD}$, Associate Professor, Department of Surgery, UFSCPA, Porto Alegre-RS, Brazil. Technical procedures, acquisition of data.

${ }^{\mathrm{v}} \mathrm{PhD}$, Chairman and Head, Department of Vascular Surgery, UFSCPA, Porto Alegre-RS, Brazil. Interpretation of data, critical revision.

\begin{abstract}
PURPOSE: To evaluated the role of oxidative stress on aging process in patients submitted to carotid endarterectomy.

METHODS: Twenty patients were divided into two groups: older group ( $\geq 70$ years old); and the younger group ( $<70$ years old). We evaluated the reactive oxygen species (ROS) concentration, nicotinamide adenine dinucleotide phosphate (NADPH)-oxidase, superoxide dismutase (SOD) and catalase (CAT) activities as so as nitrite levels in fragments of carotid arteries harvested during carotid endarterectomy for treatment of high grade carotid stenosis.

RESULTS: We observed a higher levels of ROS and NADPH oxidase activity in the older group $(\mathrm{p}<0.05)$. Furthermore, the nitrite concentration was lower in the older group $\left(14.55 \pm 5.61 \times 10^{-3}\right.$ versus $\left.26.42 \pm 8.14 \times 10^{-3} \mu \mathrm{M} ; \mathrm{p}=0.0123\right)$. However, the activities of antioxidant enzymes (CAT and SOD) were similar in both the groups.
\end{abstract}

CONCLUSIONS: Arterial aging is associated with increased concentrations of oxygen species and nicotinamide adenine dinucleotide phosphate (NADPH) oxidase activity as so as nitrite reduction in human carotid artery specimens. Maybe therapies that block NADPH oxidase activity and enhance nitrite stores would be a good strategy to reduce the effect of oxidative stress in arterial aging.

Key words: Oxidative Stress. Reactive Oxygen Species. Carotid Arteries. Endarterectomy, Carotid. 


\section{Introduction}

Atherosclerotic disease of the carotid arteries is responsible for a considerable number of all strokes and increases with aging ${ }^{1,2}$. Oxidative stress, defined as an imbalance between oxidants and antioxidants in favor of the former, plays a significant role in the pathogenesis of atherosclerotic vascular disease as well as an important determinant in the aging process ${ }^{3}$. Reactive oxygen species (ROS) such as superoxide $\left(\cdot \mathrm{O}_{2}^{-}\right)$and hydrogen peroxide $\left(\mathrm{H}_{2} \mathrm{O}_{2}\right)$ contribute to the oxidative stress damage and can be scavenged by superoxide dismutase (SOD) and catalase (CAT), respectively ${ }^{4,5}$. In the experimental setting, there is some evidence that enzyme responsible for ${ }^{-} \mathrm{O}_{2}{ }^{-}$production in the atherosclerotic arteries is the NADPH oxidase ${ }^{6}$. This enzyme is membrane bound and generates superoxide by transferring electrons from NADPH to molecular oxygen 7 . Furthermore, nitric oxide (NO), also known as endothelium-derived relaxation factor, is produced in various types of cells and it inhibits platelet aggregation, induces vascular relaxation, and impairs vascular smooth muscle cell proliferation ${ }^{8,9}$. NO is thought to exert vasculoprotective and antiapoptotic effects and decreased of its bioavailability has been linked to cardiovascular aging ${ }^{10}$. Superoxide anion reacts with NO causing peroxynitrite $\left(\bullet \mathrm{ONOO}^{-}\right)$generation, which is a well known radical which causes endothelial dysfunction ${ }^{10}$.

There are few studies assessing the oxidative stress in human carotid arteries ${ }^{8,11}$. Thereby, we investigated the role of aging on oxidative stress in human carotid arteries of patients submitted to carotid endarterectomy.

\section{Methods}

The study was approved by the local Ethics Committee and all participants gave written informed consent.

Ten patients with 70 years or older ("older group") were compared to 10 patients under 70 years old ("younger group"). All the patients were submitted to carotid endarterectomy to treat a high degree carotid stenosis provoked by atherosclerosis. The procedures were performed under general anesthesia and fragments of carotid arteries were prospectively collected to analyze the oxidative stress parameters described below. Demographic data (age and sex) and presence of symptoms were recorded. Computed tomography (CT) angiography of carotid arteries was performed in all patients. Degree of stenosis was determined according to North American Symptomatic Carotid Endarterectomy Trial (NASCET) criteria $^{12}$.

\section{Tissue collection and preparation}

The human carotid specimens were removed in the operating room and were immediately stored at $-70^{\circ} \mathrm{C}$ for further analysis of oxidative stress parameters. Carotid samples were macerate in liquid nitrogen. After that, it was homogenized $(\mathrm{KCl}$ $150 \mathrm{mmol} / \mathrm{L}$; phenyl-methyl-fluoro-sulfonyl 20mmol/L, 1:100) in the Ultra-Turrax homogenizer. Posteriorly, it was performed a sonification with the Hielscher Ultrasound Technology device ${ }^{13}$.

\section{Measurement of oxidative stress parameters}

Reactive oxygen species (ROS) concentration was measured by DCFH-DA fluorescence emission (Sigma-Aldrich, USA). Dichlorofluorescein diacetate is membrane permeable and is rapidly oxidized to the highly fluorescent 2,7-dichlorofluorescein (DCF) in the presence of intracellular ROS. The samples were excited at $488 \mathrm{~nm}$ and emission was collected with a $525 \mathrm{~nm}$ long pass filter. It was expressed as nmols per milligram of protein ${ }^{14}$. Measurement of NADPH oxidase activity was assayed with spectrophotometric method ${ }^{15}$. Nitrites levels were determined using the Griess reagent, in which a chromophore with a strong absorbance at $542 \mathrm{~nm}$ is formed by reaction of nitrite with a mixture of naphthyletilenediamine $(0.1 \%)$ and sulphanilamide $(1 \%)$. The absorbance was measured in a spectrophotometer to give the nitrite concentration ${ }^{16}$.

\section{Antioxidant enzymes activities}

Superoxide dismutase (SOD) activity, expressed as U/mg protein, was based on the inhibition of superoxide radical reaction with pyrogallol ${ }^{17}$. Catalase (CAT) activity was determined by following the decrease in $240 \mathrm{~nm}$ absorption of hydrogen peroxide $\left(\mathrm{H}_{2} \mathrm{O}_{2}\right)$. It was expressed as nmoles/mg protein ${ }^{18}$. Determination of protein concentration was measured by the method of Lowry et $a l .{ }^{19}$, using bovine serum albumin as standard.

\section{Statistical analysis}

All data are expressed as the mean \pm standard error. Comparisons between the groups were analyzed with the Student's $t$ test and exact Fisher's test. A value of $\mathrm{p}<0.05$ was considered significant.

\section{Results}

Demography data are summarized in Table 1. Average 
was significantly higher in the older group. There was no difference in the male/female proportion and presence of symptoms between the groups. Degree of carotid stenosis also were similar between the older and younger groups $(78.12 \pm 11.7 \%$ vs $83.12 \pm 11.43 \%$, respectively; $\mathrm{p}=0.432$ ).

TABLE 1 - Demographic and degree of stenosis of patients submitted to carotid endarterectomy.

\begin{tabular}{cccc}
\hline Parameter & $\begin{array}{c}\text { Older } \\
\text { group }\end{array}$ & $\begin{array}{c}\text { Younger } \\
\text { group }\end{array}$ & $\boldsymbol{p}$ value \\
\hline Age $($ mean \pm SD) & $76.1 \pm 4.4$ & $59.6 \pm 8.3$ & 0.001 \\
Male gender & $9 / 10$ & $8 / 10$ & 0.591 \\
Symptomatic & $3 / 10$ & $7 / 10$ & 0.179 \\
Degree of stenosis $(\%)$ & $78.1 \pm 11.7$ & $83.1 \pm 11.4$ & 0.432 \\
\hline
\end{tabular}

Oxidative stress parameters are demonstrated in the Figure 1 (A-E). In the older patients, we observed a higher levels of ROS and an increase in the NADPH oxidase activity in their carotid arteries when compared with young group $(\mathrm{p}<0.05)$. Furthermore, the nitrite concentration was lower in the older group when compared with the younger group $(14.55 \pm 5.61 \mathrm{x}$ $10^{-3}$ vs $\left.26.42 \pm 8.14 \times 10^{-3} \mathrm{M} ; \mathrm{p}=0.0123\right)$. However, the activities of antioxidant enzymes (CAT and SOD) were similar in both the groups.

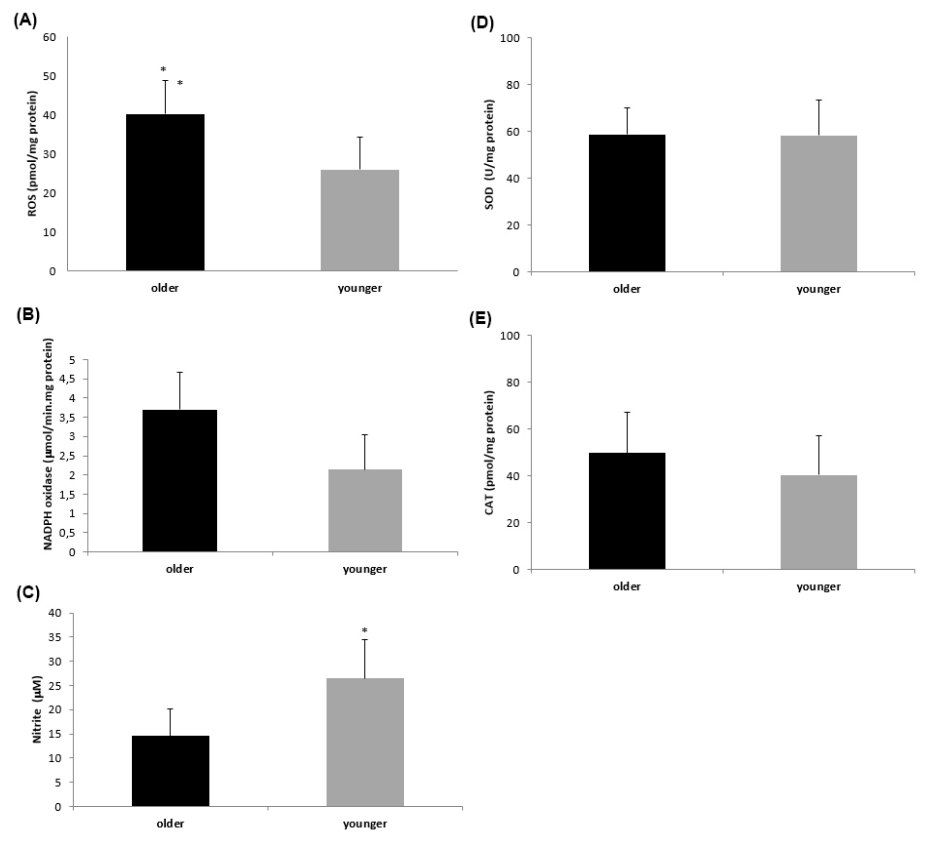

FIGURE 1 - (A) ROS levels; (B) NADPH oxidase activity; (C) Nitrite concentration; (D) CAT activity; and (E) SOD activity in human carotid arteries of older $(\geq 70$ years old) and younger $(<70$ years old) patients submitted to carotid endarterectomy. ${ }^{*} \mathrm{p}<0.05$.

\section{Discussion}

This preliminary study demonstrated that oxidative stress, evaluated by ROS concentration and NADPH oxidase activity were increased in human carotid arteries of older patients ( $\geq 70$ years old) when compared with younger patients $(<70$ years old). It has been demonstrated that arterial oxidative stress develops with aging as a consequence of excessive production of superoxide by NADPH oxidase (20). In the study of Sindler et $a l .^{21}$, there was about $100 \%$ greater of $\bullet \mathrm{O}_{2}$ - production in the aorta of old mice compared with young control group. Furthermore, Csiszar et $a l .{ }^{10}$ observed an attenuated production of ROS in mouse aortas of longer-lived mice when compared to shorterlived mice, but expression of NADPH oxidase was similar in both groups. Elevated levels of oxidative DNA damage yet were found in human atherosclerotic plaques ${ }^{22}$. Nevertheless, there are few studies in human beings reporting the role of oxidative stress in the atherosclerosis processes ${ }^{23,24}$.

It has been accepted that ROS are involved in the development of atherosclerosis ${ }^{25}$. More recently, ROS have been also implicated in other pathological processes in the vessel wall, including endothelial dysfunction, activation of matrix metalloproteinases, and vascular smooth muscle cell (VSMC) migration $^{26}$. Other mechanism by which ROS can promote vascular disease is via reduction of NO bioavailability resulting in lower vasodilator and antiapoptotic action of $\mathrm{NO}^{10,27}$. In our study, we observed a significant reduction in nitrite concentration in carotid arteries in the older group compared with young patients. Aging cell nitrite demonstrated that sodium nitrite treatment ameliorated carotid artery endothelial dysfunction in old C57BL6 mice ${ }^{21}$. Moreover, the diminished nitrite concentration in atherosclerotic arteries it is related with enhanced $\cdot \mathrm{O}_{2}^{-}$production ${ }^{8}$. In an experimental study, it was observed that nitrite concentrations were lower in old compared with young control animals. These results show that nitrite concentrations in carotid arteries decrease with aging, according to our results ${ }^{21}$.

$\mathrm{NADPH}$ oxidase is an enzyme with the primary function of generating $\bullet \mathrm{O}_{2}^{-}$. Arterial oxidative stress develops with aging as a consequence of excessive production of $\bullet \mathrm{O}_{2}{ }^{-}$by NADPH oxidase mainly ${ }^{20,21}$ and possibly via selective reductions in antioxidant enzymes, including $\mathrm{SOD}^{21}$. In our experiment, we demonstrated an elevated activity of NADPH oxidase in carotid arteries of older patients when compared with youngers. Guzik et al. ${ }^{28}$ showed that vascular NADPH oxidases are major sources of $\bullet \mathrm{O}_{2}^{-}$in human vessels and showed an association between enzymatic activity and clinical risk factors in atherosclerosis. It has characterized NADPH 
oxidase in human coronary arteries with evident atherosclerotic plaques, as well as in peripheral arteries and veins without plaques but characterized by systemic endothelial dysfunction ${ }^{29}$. Sindler $e t$ $a l{ }^{21}$ also demonstrated an increase of NADPH oxidase expression in the aorta of old compared with young control mice. These same authors also demonstrated a reduced of SOD activity in aortas of old mice ${ }^{21}$. Superoxide anion can be metabolized in $\mathrm{H}_{2} \mathrm{O}_{2}$ by SOD enzyme $^{10,30}$. By converting hydrogen peroxide into water, CAT constitutes a primary antioxidant defense system and could protect cells from ROS and its deleterious consequences ${ }^{31}$. In experimental setting, CAT leads to a delayed onset of atherosclerosis in a murine model ${ }^{32}$. Besides, longer-liver mice have more abundant expression of CAT in aortas when compared to shorter-lived mice, but expression of SOD was similar in both groups ${ }^{10}$. We did not demonstrate any difference in CAT and SOD activities between older and younger patients. In human beings, it has been shown that atherosclerotic plaques had low levels of antioxidant enzymes, but data involving CAT expression are scarces ${ }^{11}$.

The knowledge that ROS are involved in the pathogenesis of vascular disease should stimulate the development of therapies to minimize its effects. Therefore, targeting ROS production by blocking the activity of some enzymes - such as NADPH oxidase — is likely to be a far superior approach for combating oxidative stress and preventing the progression of vascular disease than previous attempts aimed at scavenging $\operatorname{ROS}^{33}$.

A rationale for therapies that block NADPH oxidase activity and enhance nitrite stores would be a good strategy to reduce the effect of oxidative stress in arterial aging. We know that this study is bring a preliminary result with a small sample size of patients which could restrict our interpretation of the results, with a potential bias for analysis. We need more robust studies to confirm our findings so that it can be justified any type of antioxidant treatment in patients with carotid disease.

\section{Conclusion}

Our results indicate that arterial aging is associated with increased concentrations of oxygen species and nicotinamide adenine dinucleotide phosphate and oxidase activity as so as nitrite reduction in arterial specimens of patients undergoing carotid endarterectomy to high grade stenosis of the carotid arteries.

\section{References}

1. Liang Y, Yan Z, Sun B, Cai C, Jiang H, Song A, Qiu C. Cardiovascular risk factor profiles for peripheral artery disease and carotid atherosclerosis among chinese older people: a population- based study. PLoS One. 2014;99(1):e85927. PMID: 24465793.

2. Selvin E, Erlinger TP. Prevalence of and risk factors for peripheral arterial disease in the United States: results from National Health and Nutrition Examination Survey, 1999-2000. Circulation. 2004;110:738-43. PMID: 15262830.

3. Zalba G, Beloqui O, San José G, Moreno UM, Fortuño A, Díez J. NADPH oxidase-dependent superoxide production is associated with carotid intima-media thickness in subjects free of clinical atherosclerotic disease. Arterioscler Thromb Vasc Biol. 2005;25:1452-57. PMID: 15860744.

4. Berlett BS, Stadtman ER. Protein oxidation in aging, disease, and oxidative stress. J Biol Chem. 1997;272:20313-6. PMID: 9252331.

5. Sigala F, Kotsinas A, Savari P, Filis K, Markantonis S, Iliodromitis EK, Gorgoulis VG, Andreadou I. Oxidized LDL in human carotid plaques is related to symptomatic carotid disease and lesion instability. J Vasc Surg. 201052:704-13. PMID: 20573470.

6. Warnholtz A, Nickenig G, Schilz E, Macharzina R, Bräsen JH, Skatchkov M, Heitzer T, Stasch JP, Griendling KK, Harrison DG, Böhm M, Meinertz T, Münzel T. Increased NADH-oxidase-mediated superoxide production in the early stages of atherosclerosis: evidence for involvement of the renin-angiotensin system. Circulation. 1999;99:2027-33. PMID: 10209008.

7. Paravicini TM, Gulluyan LM, Dusting GJ, Drummond GR. Increased NADPH oxidase activity, gp91phox expression, and endothelium-dependent vasorelaxation during neointima formation in rabbits. Circ Res. 2002;91:54-61. PMID: 12114322.

8. Tanner FC, Loo B, Shaw S, Greubert H, Bachschmid MM, Berrozpe M, Rozenberg I, Blau N, Siebenmann R, Schmidli J, Meyer P, Lüscher TF. Inactivity of nitric oxide synthase gene in the atherosclerotic human carotid artery. Basic Res Cardiol. 2007;102:308-17. PMID: 17356797.

9. Chou T-C, Yen M-H, Li C-Y, Ding Y-A. Alterations of nitric oxide synthase expression with aging and hypertension in rats. Hypertension. 1998;31:643-8. PMID: 9461235.

10. Csiszar A, Labinskyy N, Zhao X, Hu F, Serpillon S, Huang Z, Ballabh P, Levy RJ, Hintze TH, Wolin MS, Austad SN, Podlutsky A, Ungvari Z. Vascular superoxide and hydrogen peroxide production and oxidative stress resistance in two closely related rodent species with disparate longevity. Aging Cell. 2007;6:783-97. PMID: 17925005.

11. Lepedda AJ, Zinellu A, Nieddu G, Zinellu E, Carru C, Spirito R, Guarino A, De Muro P, Formato M. Protein sulfhydryl group oxidation and mixed-disulfide modifications in stable and unstable human carotid plaques. Oxid Med Cell Longev. 2013;2013:403973. PMID: 23431411.

12. Barnett HJ, Taylor DW, Eliasziw M, Fox AJ, Ferguson GG, Haynes RB, Rankin RN, Clagett GP, Hachinski VC, Sackett DL, Thorpe KE, Meldrum HE, Spence JD. Benefit of carotid endarterectomy in patients with symptomatic moderate or severe stenosis. North American Symptomatic Carotid Endarterectomy Trial Collaborators. N Engl J Med. 1998;339:1415-25. PMID: 9811916.

13. Sartorio CL, Fraccarollo D, Galuppo P, Leutke M, stefanon I, Bauersachs J. Mineralocorticoid receptor blockade improve vasomotor dysfunction and vascular oxidative stress after myocardial infarction. Hypertension. 200750(5):919-25. PMID: 17846350.

14. LeBel CP, Ischiropoulos H, Bondy SC. Evaluation of the probe 2',7'-dichlorofluorescin as an indicator of reactive oxygen species formation and oxidative stress. Chem Res Toxicol. 1992;5(2):22731. PMID: 1322737.

15. Wei Y, Sowers JR, Nistala R, Gong H, Uptergorve GM, Clark SE, Morris EM, Szary N, Manrique C, Stump CS. Angiotensin IIinduced NADPH oxidase activation impairs insulin signaling in skeletal muscle cells. J Biol Chem. 2006;281(46): 35137-46. PMID: 16982630 . 
16. Granger DL, Anstey NM, Miller WC, Weinberg JB. Measuring nitric oxide production in human clinical studies. Methods Enzymol. 1999;301:49-61. PMID: 9919553.

17. Marklund SL. Superoxide dismutase isoenzymes in tissues and plasma from New Zealand black mice, nude mice and normal BALB/c mice. Mutat Res. 1985;148:129-34. PMID: 3969077.

18. Aebi H. Catalase in vitro. Methods Enzymol. 1984;105:121-6. PMID: 6727660.

19. Lowry $\mathrm{OH}$, Rosebrough NJ, Farr AL, Randall RJ. Protein measurement with the folin phenol reagent. J Biol Chem. 1951;193:265-75. PMID: 14907713 .

20. Durrant JR, Seals DR, Connell ML, Russell MJ, Lawson BR, Folian BJ, Donato AJ, Lesniewski LA. Voluntary wheel running restores endothelial function in conduit arteries of old mice: direct evidence for reduced oxidative stress, increased superoxide dismutase activity and downregulation of NADPH oxidase. J Physiol. 2009;587:327185. PMID: 19417091.

21. Sindler AL, Fleenor BS, Calvert JW, Marshall KD, Zigler ML, Lefer DJ, Seals R. Nitrite supplementation reverses vascular endothelial dysfunction and large elastic artery stiffness with aging. Aging Cell. 2011;10(3):429-37. PMID: 21276184.

22. Martinet W, Knaapen WM, Meyer GRY, Herman AG, Kockx MM. Elevated levels of oxidative DNA damage and DNA repair enzymes in human atherosclerotic plaques. Circulation. 2002;106:927-32. PMID: 12186795.

23. Guzik TJ, Chen W, Gongora MC, Guzik B, Lob HE, Mangalat D, Hoch N, Dikalov S, Rudzinski P, Kapelak B, Sadowski J, Harrison DG. Calcium-dependent NOX5 nicotinamide adenine dinucleotide phosphate oxidase contributes to vascular oxidative stress in human coronary artery disease. J Am Coll Cardiol. 2008;52:1803-9. PMID: 19022160.

24. Guzik TJ, Olszanecki R, Sadowski J, Kapelak B, Rudzinski P, Jopek A, Kawczynska A, Ryszawa N, Loster J, Jawien J, CzesnikiewiczGuzik M, Channon KM, Korbut R. Superoxide dismutase activity and expression in human venous and arterial bypass graft vessels. J Physiol Pharmacol. 2005;56:313-23. PMID: 15985711.

25. Jones DP. Radical-free biology of oxidative stress. Am J Physiol Cell Physiol. 2008;295:C849-68. PMID: 18684987.

26. Taniyama Y, Griendling KK. Reactive oxygen species in the vasculature: molecular and cellular mechanisms. Hypertension. 2003;42:1075-81. PMID: 14581295.

27. Forstermann U. Nitric oxide and oxidative stress in vascular disease. Pflugers Arch. 2010;459:923-39. PMID: 20306272.
28. Guzik TJ, West NE, Black E, McDonald D, Ratnatunga C, Pillai $\mathrm{R}$, Channon KM. Vascular superoxide production by NAD $(\mathrm{P}) \mathrm{H}$ oxidase: association with endothelial dysfunction and clinical risk factors. Circ Res. 2000;86:E85-90. PMID: 10807876.

29. Konior A, Schramm A, Czesnikiewicz-Guzik M, Guzik TJ. NADPH oxidases in vascular pathology. Antioxid Redox Signal. 2014;20:2794-814. PMID: 24180474.

30. Schramm A, Matusik P, Osmenda G, Guzik TJ. Targeting NADPH oxidases in vascular pharmacology. Vascul Pharmacol. 2012:56(56):216-31. PMID: 22405985.

31. Nivet-Antoine V, Labat $\mathrm{C}$, Shamieh S, Dulcire $\mathrm{X}$, Cottart $\mathrm{CH}$, Beaudeux J-L. Zannad F, Visvikis-Siest S, Benetos A. Relationship between catalase haplotype and arterial aging. Atherosclerosis. 2013;227:100-5. PMID: 23340375.

32. Yang $\mathrm{H}$, Zhou L, Wang Z, Roberts LJ 2nd, Zhao Y, Guo Z. Overexpression of antioxidant enzymes in ApoE-deficient mice suppresses benzo(a)pyrene-accelerated atherosclerosis. Atherosclerosis. 2009;207:51-8. PMID: 19409565.

33. Drummond GR, Selemidis S, Griendling KK, Sobey CG. Combating oxidative stress in vascular disease: NADPH oxidases as therapeutic targets. Nat Rev Drug Discov. 2011;10(6): 453-71. PMID: 21629295.

\section{Correspondence:}

Márcio Luís Lucas

Rua Passo da Pátria, 515/1001

90460-060 Porto Alegre - RS Brasil

Tel.: (55 51)3214-8076

mlucasvascular@hotmail.com

Received: Apr 20, 2016

Review: Jun 23, 2016

Accepted: July 22, 2016

Conflict of interest: none

Financial source: none

${ }^{1}$ Research performed at Department of Vascular Surgery, Universidade Federal de Ciências da Saúde de Porto Alegre (UFCSPA), and Department of Cardiovascular Physiology, Universidade Federal do Rio Grande do Sul (UFRGS), Porto Alegre-RS, Brazil. 